\title{
An Analysis of Students' Scientific Literacy Skills in State Senior High Schools throughout Central Tapanuli District
}

\author{
Hotrimsyah Simbolon \\ Biology Education Postgraduate \\ State University of Medan \\ Medan, Indonesia \\ rimsyahsimbolon@gmail.com
}

\author{
Martina Restuati Simbolon \\ Biology Education Postgraduate \\ State University of Medan \\ Medan, Indonesia
}

\author{
Fauziyah Harahap \\ Biology Education Postgraduate \\ State University of Medan \\ Medan, Indonesia
}

\begin{abstract}
This study was conducted for students in State High Schools throughout Central Tapanuli District with the aims were to find out: (1) the students' scientific literacy skills; (2) the correlation between the parents' formal educational background and students' scientific literacy skills; $(3)$ the correlation between the science learning intensity and students' scientific literacy skills; and (4) the correlation between the science learning processes in schools and students' scientific literacy skills. The population were all students of XI-Science Program in State Senior High Schools throughout Central Tapanuli District with the sample was taken randomly with 256 students. This type of research was descriptive correlative research. The research instruments were tests of students' scientific literacy skills, and questionnaires of students' scientific literacy factors, namely: the parents' formal educational background, the learning science intensity, and the students' science learning processes. Data analysis techniques used in this study included descriptive analysis and correlative analysis using multiple regression analysis at a significant level $\alpha=0.05$. The results showed that: (1) the students' scientific literacy skills of XI-Science Program in State Senior High Schools throughout Central Tapanuli District belong to the poor category; (2) there was a significant corelation between the parents' formal educational background and students' scientific literacy skills throughout Central Tapanuli District $\left(t_{\text {count }}=2.603 ; P=0.010\right)$; (3) there was a significant correlation between the learning science intensity and students' scientific literacy skills throughout Central Tapanuli District $\left(t_{\text {count }}=4.083 ; P=0,000\right)$; and (4) there was a significant correlation between the science learning processes and students' scientific literacy skills throughout Central Tapanuli District $\left(t_{\text {count }}=12,644 ; P=0,000\right)$. The results of this study implied that the role and parents' educational backgrounds, science learning intensity, and scientific literacy-based students' learning process in schools had a significant correlation and influence that could improve students scientific literacy skills.
\end{abstract}

Keywords - Scientific Literacy; Parents' Formal Education; Science Learning Intensity; Science Learning Process

\section{INTRODUCTION}

In the Era of Industrial Revolution 4.0 provides opportunities and challenges for Human Resources, especially in Indonesia. The role of human beings is gradually taken over by automatic machinery which results in an increasing number of unemployed people. This of course will add to the burden of local and national problems. Therefore, to take advantage of opportunities and answer the challenges of industrial revolution 4.0, human resources need to be enhanced in literacy capabilities which include data literacy, technology literacy, and human literacy.

Data literacy skills aim to improve skills in processing and analyzing data in the interest of improving public and business services. Technology literacy aims to demonstrate the ability to utilize digital technology to process data and information. Whereas compulsory human literacy is mastered because it aims to show the elements of soft skills or individual character development to be able to collaborate, be adaptive and be wise in this digital information age. Therefore the importance of scientific literacy in humans in utilizing technology in the era of the Industrial Revolution 4.0 at this time.

Scientific literacy is an ability related to the use of science and technology. Program for International Student Assessment (PISA) (2010) states that scientific literacy is the ability to use science knowledge, identify questions, draw conclusions based on evidence to understand and help make decisions regarding nature and changes made to nature through human activities. Gormally, et al. (2012) interpreted that scientific literacy ability as a person's ability to distinguish scientific facts from various information, recognize and analyze the use of scientific inquiry methods and the ability to organize, analyze, interpret quantitative data and scientific information.

Through scientific literacy, students can improve their ability to think critically, logically, reflective, metacognitive, and creative called High Order Thinking Skills, which are students able to solve problems, make decisions, think critically and think creatively. The results of the PISA (Program for International Student Assessment) are developed 
by several developed countries in the world that are members of the Organization for Economic Cooperation and Development (OECD) which is a literacy study that aims to periodically examine students' ability to read (reading literacy), mathematics (literacy literacy), and science (scientific literacy) concluded that in general science literacy abilities of Indonesian students are still low. The results of the PISA (Program for International Student Assessment) Study Based on Science Literacy of Indonesian students from 2006 ranked $50^{\text {th }}$ out of 57 countries with a score of 395 . Ranking of scientific literacy abilities of Indonesian students continued to decline which in 2009 was ranked $60^{\text {th }}$ out of 65 countries with score 383 , and in 2012 ranked $64^{\text {th }}$ out of 65 countries with a score of 382, while in 2015 the score of Indonesian students' literacy skills increased by 403 by ranking $62^{\text {nd }}$ out of 70 countries (source: www.oecd.org/pisa).

The survey conducted by the Trends in International Mathematics and Science Study, TIMSS (every four years) showed that students' average science achievement scores were below the International score average. The results of the 2007 TIMSS (Trends in International Mathematics and Science Study) survey showed that the average score of Indonesian students' science achievements was 427 with a ranking of 35 out of 49 countries. The scientific achievements of Indonesian students continued to decline, which in 2011 ranked $40^{\text {th }}$ out of 42 countries with a score of 406 , and in 2015 ranked $45^{\text {th }}$ out of 48 countries with a score of 397 (source: www.www.iea.nl/timss).

The Province of North Sumatra continues to work to overcome literacy problems, read, write, count to eradicate illiteracy. This is revealed from the 2016 Most Littered Nation In the World study data that reading interest in Indonesia occupied rank 60 from 61 countries (webcapp.ccsu.edu). The low index of reading interest of Indonesian people must be resolved especially in the Province of North Sumatra in order to be able to become a province of literacy. The problem of the low reading interest of the Indonesian people comes from the absence of a place or reminder for the public to read. North Sumatra is the fourth province to declare itself a province of literacy after DKI Jakarta, Riau and West Nusa Tenggara. This is evidenced by the existence of two regional districts in North Sumatra, namely Labuhanbatu and Serdangbedagai Districts that have been set by the Minister of Education and Culture as a national literacy pilot district. Both regions have a high commitment to promoting literacy. Even Serdangbedagai District got the highest score in the regional literacy development index survey conducted by the Minister of Education and Culture (source: Kompas, 2017).

In the Middle School of Central Tapanuli District, it was found that the learning process carried out was still conventional, namely the question and answer lectures, and the contents of the evaluation instrument assessment of student learning outcomes had not yet referred to scientific literacy. So that these results lead to a low ability of students to use or use scientific concepts, principles, laws, and theories contained in biological matter in solving problems in everyday life, and making decisions. This states that the ability of students is still weak in science, even though with the development of the times the foundation of science is needed to communicate and develop technology. This shows that students have difficulty in getting meaning and using science to solve various problems that occur in everyday life that actually require a good understanding of science (Haristy, Enawaty \& Lestari, 2013), therefore, scientific literacy is in the form of ability use science knowledge to describe conclusions based on scientific facts. So that these conclusions need to be outlined in the evaluation of science learning in the classroom.

\section{RESEARCH AND METHOD}

This study was carried out in State Senior High Schools throughout Central Tapanuli District from February to November 2018. The population were all students of XIScience Program in State Senior High Schools (SMA Negeri) throughout Central Tapanuli District with the sample was taken randomly with 256 students presented in Table 3.1.

TABLE 1. POPULATION AND SAMPLE OF THE STUDY

\begin{tabular}{clcc}
\hline No & \multicolumn{1}{c}{ Schools } & Population & Samples \\
\hline 1 & SMA Negeri 1 Andam & 88 & \\
& Dewi & & 33 \\
2 & SMA Negeri 1 Barus & 68 & 36 \\
3 & SMA Negeri 1 & 173 & \\
& Pinangsori & & 26 \\
4 & SMA Negeri 1 Sorkam & 46 & 21 \\
5 & SMA Negeri 1 Sorkam & 138 & \\
& Barat N & 107 & 35 \\
6 & SMA Negeri 1 Tukka & 38 & 34 \\
7 & SMA Negeri 2 Tukka & 102 & 35 \\
8 & SMA Negeri & & 36 \\
& Sibabangun & $\mathbf{7 6 0}$ & $\mathbf{2 5 6}$ \\
\hline
\end{tabular}

This type of research was descriptive correlative research. The research instruments were tests of students' scientific literacy skills, and questionnaires of students' scientific literacy factors, namely: the parents' formal educational background, learning science intensity, and students' science learning processes. Data analysis techniques used in this study included descriptive analysis and correlative analysis using multiple regression analysis at a significant level $\alpha=0.05$.

\section{RESULTS AND DISCUSSION}

\section{A. The Correlation between Parents' Formal Educational Background and Students' Scientific Literacy Skills}

Based on the results of a simple correlation analysis $(r)$, the correlation between the parents' formal educational background and students' scientific literacy skills was 0.161 . This showed that there was a strong correlation between the parents' formal educational background with students' scientific literacy skills of class XI-Science Program in State Senior High Schools throughout Central Tapanuli District. 
Due to the value of $r$ was positive, it means that the higher the parents' formal educational background, the more it increases students' scientific literacy skills.

Based on the analysis of the Model Summary obtained: (1) the value of $R$ was positive 0.161 , then there was a positive correlation between the parents' formal educational background with students' scientific literacy skills in State Senior High Schools throughout Central Tapanuli District; and (2) determination coefficient value $R 2$ was 0.026 , then the parents' formal educational background contributes to the students' scientific literacy skills of $2.6 \%$.

Based on the results of the analysis of variance obtained $F_{\text {count }}$ value of 6.778 with a significant value of 0.010 smaller than 0.05. Furthermore, the parents' formal educational background influences simultaneously (jointly) the students' scientific literacy skills $\left(F_{\text {count }}=6.778 ; \mathrm{P}=0.010\right)$.

Based on the results of the coefficient analysis between the variables of parents' formal educational background on scientific literacy skills, students of class XI-Science Program in State Senior High Schools throughout Central Tapanuli District were obtained: (1) value calculated for parents' formal educational background variable of 2,603 with significance level of 0.010 was smaller than 0.05 . Furthermore, partially the parents' formal educational background variable had a significant effect on students' scientific literacy skills $\left(t_{\text {count }}=\right.$ 2.603; $\mathrm{P}=0.010$ ); and (2) the coefficient value of the parents' formal educational background variable of 0.847 with a constant value of 32.177. Furthermore, the linear line equation in this study was $\hat{\mathrm{Y}}=0.847 \mathrm{X}+32,177$. The correlation between parents' formal educational background and students' scientific literacy skills was presented in Figure 1.

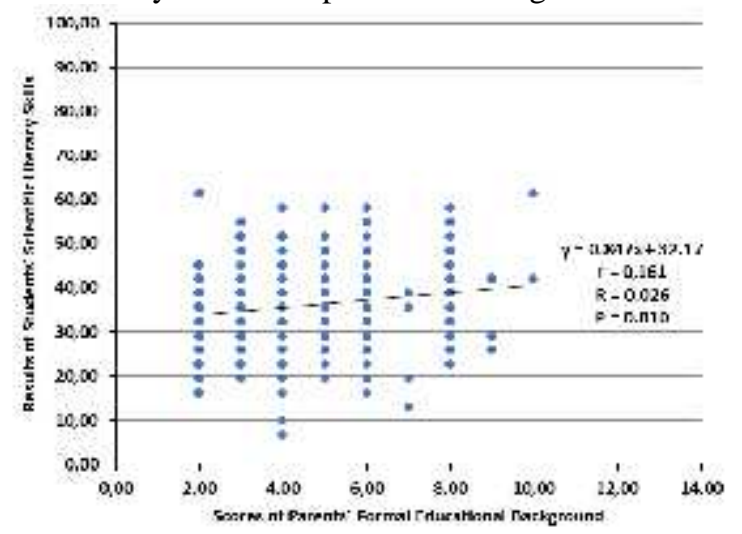

Fig. 1. The Correlation between Parents' Formal Educational Background and Students' Scientific Literacy Skills of Class XI-Science Program in State Senior High Schools throughout Central Tapanuli District

\section{B. The Correlation between the Science Learning Intensity and Students' Scientific Literacy Skills}

Based on the results of simple correlation analysis ( $r$, the correlation between the science learning intensity and students' scientific literacy skills was 0.248 . This showed that there was a strong correlation between the science learning intensity with students' scientific literacy skills of class XI-
Science Program in State Senior High Schools throughout Central Tapanuli District. Due to the value of $r$ was positive, it means that the higher the science learning intensity, the more it increases students' scientific literacy skills.

Based on the results of the Model Summary analysis, it was obtained: (1) the value of $R$ was positive 0.248 , then there was a positive correlation between the science learning intensity with students' scientifc literacy skills of XI-Science Program in State Senior High School throughout Central Tapanuli District; and (2) the coefficient of determination $R 2$ was 0.062 , furthermore the science learning intensity contributes to the students' scientific literacy skills of $6.2 \%$.

Based on the results of the analysis of variance obtained $F_{\text {count }}$ value of 16,667 with a significant value of 0,000 smaller than 0.05 . Furthermore, the science learning intensity had a simultaneous (jointly) influence on students' scientific literacy skills $\left(F_{\text {count }}=16,667 ; \mathrm{P}=0,000\right)$.

Based on the results of the coefficient analysis between the science learning intensity on scientific literacy skills, students of class XI-Science Program in State Senior High Schools throughout Central Tapanuli District were obtained: (1) the value calculated for science learning intensity variable of 4,083 with a significance level of 0,000 smaller than 0,05 . Furthermore, partially the science learning intensity variable had a significant effect on students' science literacy skills $\left(t_{\text {count }}=4.083 ; \mathrm{P}=0,000\right)$; and (2) the coefficient value of the science learning intensity variable of 0.964 with a constant value of 24.728. Furthermore, the linear line equation in this study was $\hat{\mathrm{Y}}=0.964 \mathrm{X}+24.728$. The correlation between science learning intensity and students' science literacy skills of Class XI-Science Program in State Senior High Schools throughout Central Tapanuli District was presented in Figure 2.

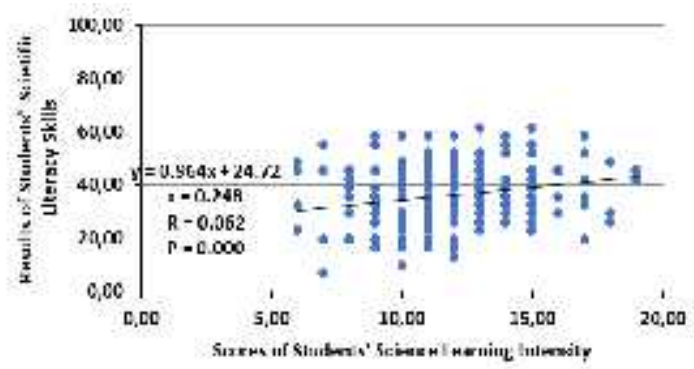

Fig. 2. The Correlation between Science Learning Intensity and Students' Scientific Literacy Skills of Class XI-Science Program in State Senior High Schools throughout Central Tapanuli District

\section{The Correlation between Science Learning Processes in Schools and Students' Scientific Literacy Skills}

Based on the results of a simple correlation analysis $(r)$, the correlation between the science learning processes in schools and students' scientific literacy skills was 0.622 . This showed that there was a strong correlation between the science learning processes in schools with students' scientific literacy skills of class XI-Science Program in State Senior High Schools throughout Central Tapanuli District. Due to the value 
of $r$ was positive, it means that the higher the science learning processes in schools, the more it increases students' scientific literacy skills.

Based on the analysis of the Model Summary obtained: (1) the value of $R$ value was positive 0.622 , then there was a positive correlation between the science learning processes in schools with students' scientific literacy skills of class XIScience Program in State Senior High Schools throughout Central Tapanuli District; and (2) the coefficient of determination $R 2$ was 0.386 , furthermore the science learning processes in schools contributes to the students' scientific literacy skills of $38.6 \%$.

Based on the results of the analysis of variance obtained $F_{\text {count }}$ value of 159,870 with a significance value of 0,000 smaller than 0.05 . Furthermore, the science learning processes in schools had a simultaneous (jointly) influence on students' scientific literacy skills $\left(F_{\text {count }}=159,870 ; \mathrm{P}=0,000\right)$. Based on the results of the coefficient analysis between the variable of the science learning processes in schools towards students' scientific literacy skills were obtained: (1) the calculated value for the science learning processes in schools was 12,644 with significance level of 0,000 smaller than 0.05 . Furthermore, partially the science learning processes in schools had a significant effect on students' scientific literacy skills $\left(t_{\text {count }}=12,644 ; \mathrm{P}=0,000\right)$; and (2) the variable coefficient value of the science learning processes in schools was 0.724 with a constant value $=-7.737$. Furthermore, the linear line equation in this study was $\hat{\mathrm{Y}}=0.724 \mathrm{X}-7.737$. The correlation between science learning processes in schools and students' scientific literacy skills of Class XI-Science Program in State Senior High Schools throughout Central Tapanuli District was presented in Figure 3.

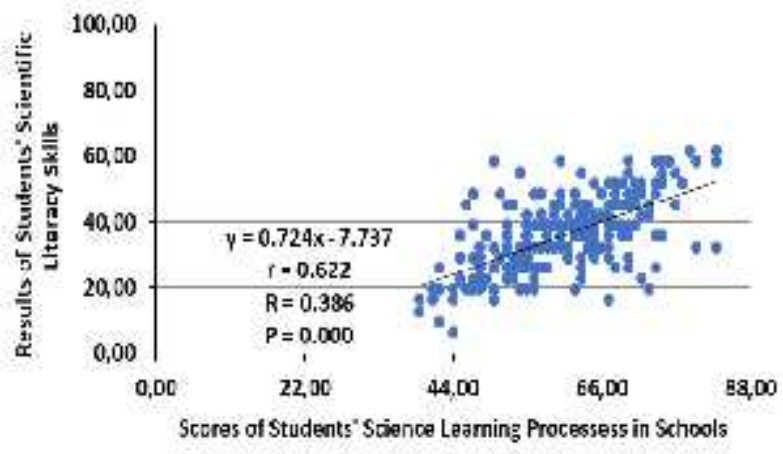

Fig. 3. The Correlation between Science Learning Processes in Schools and Students' Scientific Literacy Skills of Class XI-Science Program in State Senior High Schools throughout Central Tapanuli District

\section{CONCLUSION}

Based on the results of the study that has been described, it can be concluded that: (1) the students' scientific literacy skills of Class X-Science Program in State Senior High Schools throughout Central Tapanuli District belong to the poor category; (2) there was a significant correlation between parents' formal educational background and students' scientific literacy skills of class XI-Science Program in State Senior High Schools throughout Central Tapanuli District $(\mathrm{r}=0,161)$; (3) there was a significant correlation between science learning intensity and students' scientific literacy skills of class XIScience Program in State Senior High Schools throughout Central Tapanuli District $(\mathrm{r}=0,248)$; and (4) there was a significant correlation between the science learning processes in schools and students' scientific literacy skills of class XIScience Program in State Senior High Schools throughout Central Tapanuli District $(r=0,622)$

\section{ACKNOWLEDGMENT}

Thank you for my thesis supervisors, Mrs. Dr. Martina Restuati, M.Si. and Mrs. Dr. Fauziyah Harahap, M.Si., who helped me a lot in completing this article and all the State Senior High Schools in Central Tapanuli District that helped me a lot in collecting data for the completion of this article.

\section{REFERENCES}

[1] Arikunto, S. 2006. Prosedur Penelitian (Suatu Pendekatan Praktik Edisi Revisi VI). Jakarta: Rineka Cipta.

[2] Bybee, R. W. 2009. PISA'S 2006 Measurement of Scientific Literacy: An Insider's Perspective for the U.S. A Presentation for the NCES PISA Research Conference. Washington: Science Forum and Science Expert Group.

[3] Darling-Hammond, L., dan Brannsford, J. 2005. Preparing Teacher for a Changing World. San Franciso: Jossy- Bass Publishing.

[4] Delin, D. J., Djamas, D. dan Yohandri. 2015. Analisis Karakteristik Peserta Didik Berdasarkan Dimensi Literasi Sains pada Pengembangan Performance Assessment Berbasis Discovery Learning. Prosiding Seminar Nasional Pembelajaran Fisika. Universitas Negeri Padang. Padang, 7 November 2015. ISBN 978-602-14657-1-4. Halaman: 310314.

[5] DeBoer, G. E. 2000. Scientific Literacy: Another Look at its Historical and Contemporary Meanings and Its Relationship to Science Education Reform. Journal of Research in Science Teaching, 37(6): 582-601.

[6] Depdiknas. 2007. Kajian Kurikulum Mata Pelajaran IPA. Jakarta: Depdiknas.

[7] Diana, S., Rachmatulloh, A., dan Rahmawati, E. S. 2016. High Schoo Students' Scientific Literacy Profile Based on Scientific Literacy Assessments (SLA) Instruments. In Prosiding Seminar Biologi, 12(1): 285-291.

[8] Dimyati, dan Mudjiono. 2013. Belajar dan Pembelajaran. Jakarta Rineka Cipta.

[9] Djamarah, S. B. 2002. Rahasia Sukses Belajar. Jakarta: Rineka Cipta

[10] Ekohariadi. 2009. Faktor-faktor yang Mempengaruhi Literasi Sains Siswa Indonesia Berusia 15 Tahun. Jurnal Pendidikan Dasar, 10(1): 2841.

[11] Elvadola, C. 2016. Profil Kompetensi Literasi Sains Siswa Berdasarkan The Programme for International Student Assesment (PISA) pada Konten Biologi (Kuasi Deskriptif Siswa Kelas IX SMP se-Kecamatan Kemiling di Bandar Lampung). Lampung: Fakultas Keguruan dan Ilmu Pendidikan Universitas Lampung.

[12] Fitriani. 2018. Analisis Kemampuan Literasi Sains Biologi Siswa SMA kelas XI IPA Se-Kabupaten Aceh Tamiang. Tesis tidak diterbitkan. Medan: Program Pascasarjana UNIMED.

[13] Firman, H. 2007. Laporan Hasil Analisis Literasi Sains Berdasarkan Hasil PISA Nasional Tahun 2006. Puspendik.

[14] Fives, H., Huebner, W., Birnbaum, A. S., dan Nicolich, M. 2014 Developing a measure of scientific literacy for middle school students. Science Education, 98(4): 549-580.

[15] Gormally, C., Peggy B., dan Mary, L. 2012. Developing a Test of Scientific Literacy Skills (TOSLS): Measuring Undergraduates * Evaluation of Scientific Information and Arguments. CBE-Life Sciences Education. 11(1): 364-377. 
[16] Haristy, D. R., Enawaty, E., dan Lestari, I. 2013. Pembelajaran Berbasis Literasi Sains pada Materi Larutan Elektrolit dan Non Elektrolit di SMA Negeri 1 Pontianak. Pontianak: FKIP Untan.

[17] Holbrook, J. 2005. Making Chemistry Teaching Relevant. Chemical Education International. 6(1): 1-12.

[18] Imaningtyas, C. D., Karyanto, P., Nurmiyati, N., dan Asriani, L. 2016. Penerapan E-Module Berbasis Problem Based Learning untuk Meningkatkan Literasi Sains dan Mengurangi Miskonsepsi pada Materi Ekologi Siswa Kelas X MIA 6 SMAN 1 Karanganom Tahun Pelajaran 2014/2015. Jurnal Bioedukasi, 9(1): 4-10.

[19] Kemendikbud. 2014. Peraturan Menteri Pendidikan dan Kebudayaan Republik Indonesia Nomor 58 Tahun 2014. Sekertariat Jendral. Jakarta

[20] Kharizmi, M. 2015. Kesulitan Siswa Sekolah Dasar dalam Meningkatkan Kemampuan Literasi. Jupendas, ISSN 2355-3650, 2(2): 11-21.Kompas. 2017. Giatkan Membaca, Sumut Dekalarasikan Diri sebagai Provinsi Literasi.https://regional.kompas.com/read/2017/05/21/18011391/giatkan membaca.sumut.deklarasikan.diri.sebagai.provinsi.literasi, diakses 01 April 2018.

[21] Kurnia, F., Zulherman, dan Fathurohman, A. 2014. Analisis Bahan Ajar Fisika SMA Kelas XI Di Kecamatan Indralaya Utara Berdasarkan Kategori Literasi Sains. Jurnal Inovasi dan Pembelajaran Fisika, 1(1): 43-47.

[22] Kusuma, R. C. D. 2012. Pengaruh Latar Belakang Sosial Ekonomi Keluarga dan Sikap pada Sains Terhadap Kemampuan Literasi Sains (Scientific Literacy) Mahasiswa Sains dan Teknologi Universitas Airlangga Surabaya. Skripsi tidak diterbitkan. Fakultas: Ilmu Sosial Ilmu Politik, Program Studi: Perpustakaan dan Ilmu Informasi. Surabaya: Universitas Airlangga.

[23] Laugksch, R. C. 2000. Scientific Literacy: A Conceptual Overview. John Wiley \& Sons, Inc. Sci. Ed, 84(1): 71-94.

[24] Laurent,. L. S., dan Giasson, J. 2005. Effect of Family Literacy Program Adapting Parental Intervension to First Grader's Evolution of Reading and Writing Abilities. Jurnal of Early Chilhood Literacy, 5(3): 253-278.

[25] Maryuningsih, Y. 2013. Penerapan Problem Based Learning dalam Pembelajaran sebagai Upaya Membangun Kemandirian Belajar untuk Meningkatkan Keterampilan Kerja Ilmiah dan Literasi Sains pada Mahasiswa. Jurnal Scientiaeducatia, 2(1): 1-19.

[26] Mawardini, A. 2015. Profil Literasi Sains Siswa SMP pada Pembelajaran IPA Terpadu Tema Pencemaran Lingkungan. Tesis. Bandung: Universitas Pendidikan Indonesia.

[27] Musthafa, B. 2014. Literasi Dini dan Literasi Remaja: Teori, Konsep, dan Praktik. Bandung: CREST.

[28] Nbina, J. B., dan Obomanu, B. J. 2010. The Meaning of Scientific Literacy: A Model of Relevance in Science Education. Academic Leadership Journal, 8 (4)

[29] Nurlaili. 2011. Analisis Buku Ajar Biologi Berorientasi Literasi Sains di Kabupaten Aceh Barat yang Digunakan di Sekolah Tingkat SMA/MA kelas X. Tesis tidak diterbitkan. Medan: Program Pascasarjana UNIMED

[30] Odja, A. H., dan Payu, C. S. 2014. Analisis Kemampuan Awal Literasi Sains Siswa Pada Konsep IPA. Prosiding Seminar Nasional Kimia, ISBN: 978-602-0951-00-3. Halaman: 40-47.

[31] OECD. 2003. Literacy Skills for The World of Tomorrow: Further Result From PISA 2000. Paris: Unesco Institute for Statistic.

[32] OECD. 2013. PISA 2012 Result: What Students Know and can DoStudent Performance in Mathemathics, Reading and Science (Volume I). PISA: OECD Publishing.

[33] OECD. 2014. PISA 2012 Results in Focus: What 15 Year Olds Know and What They Can Do With What They Know. (Online). Tersedia: http://www.oecd.org/pisa/keyfindings/pisa-2012-results-overview.pdf. diakses 01 Juni 2015.
[34] OECD. 2015. Survey International Program for International Student Assessment (PISA). (Online) (http: // www.oecd.org/pisa), diakses 01 Juni 2015.

[35] Park, H. 2008. Home Literacy Environment and Children's Reading Performance: A Comparative Study of 25 Countries. Educational Research and Evaluation, 14 (6): 489-505.

[36] PISA. 2010. Assessment Framework Key Competencies In Reading, Mathematics and Science. OECD.

[37] Poedjiadi, A. 2005. Sains, Teknologi Masyarakat: Pendekatan Pembelajaran Kontekstual Bermuatan Nilai. Bandung: Remaja Rosdakarya.

[38] Ridwan, M. S., Mardhiyyah, L. A., dan Rusilowati, A. 2013. Pengembangan Instrumen Asesmen dengan Pendekatan Kontekstual untuk Mengukur Level Literasi Sains Siswa. Universitas Negeri Semarang. Seminar Nasional Evaluasi Pendidikan Tahun 2013. ISBN 978-602-14215-0-5. Halaman: 177-190.

[39] Rizkita, L., Suwono, H., dan Susilo, H. 2016. Analisis Kemampuan Awal Literasi Sains Siswa Kota Malang. Prosiding Seminar Nasional II Tahun 2016, Kerjasama Prodi Pendidikan Biologi FKIP dengan Pusat Studi Lingkungan dan Kependudukan (PSLK) Universitas Muhammadiyah Malang. Malang, 26 Maret 2016, Halaman: 771-781.

[40] Rohmah, M., Zahirman, dan Erlinda, S. 2012. Pengaruh Penggunaan Strategi Pembelajaran Crossword Puzzle terhadap Minat Belajar PKN Siswa Kelas VIII di SMP Negeri 1 Kampar Kiri Tengah Kecamatan Kampar Kiri Tengah Kabupaten Kampar. Riau: Universitas Riau.

[41] Rohmi, P. 2015. Penerapan Levels Of Inquiry untuk Meningkatkan Domain Kompetensi dan Pengetahuan Sains Siswa SMP pada Tema Pencemaran Lingkungan. Makalah. Universitas Indonesia. Perpustakaan UPI.

[42] Rusilowati, A., Kurniawati, L., dan Nugroho, S. E. 2016. Developing an Instrument of Scientific Literacy Assessment on the Cycle Theme. International Journal of Environmental \& Science Education, 11(12): 5718-5727.

[43] Rustaman, A. 2011. Membangun Literasi Sains Siswa. Bandung: Humaniora.

[44] Slameto. 2010. Belajar dan Faktor-faktor yang Memengaruhinya. Jakarta: Rineka Cipta.

[45] Soemanto, W. 2012. Psikologi Pendidikan. Jakarta: Rineka Cipta.

[46] Soobard, R., dan Rannikmae, M. 2011. Assessing Student's Level of Scientific Literacy Using Interdisciplinary Scenarios. Science Education International, 22(2): 133-144

[47] Sudiatmika. 2012. Pengembangan Alat Ukur Tes Literasi Sains Siswa SMP dalam Konteks Budaya Bali. Disertasi Doctor, tidak diterbitkan. Bandung: Universitas Pendidikan Indonesia.

[48] Sulistiyowati, S. 2001. Cara Belajar Yang Efektif dan Efisien. Pekalongan: Cinta Ilmu.

[49] Toharudin, U., Hendrawati, S., dan Rustaman, A. 2011. Membangun Literasi Sains Peserta Didik. Bandung: Humaniora.

[50] Tohir, M. 2016. Hasil PISA Indonesia Tahun 2015 Mengalami Peningkatan. Tersedia Online: https://matematohir.wordpress.com/2016/12/08/hasil-pisaindonesiatahun-2015-mengalami-peningkatan/ (08 Desember 2016).

[51] Widyatiningtyas, R. 2002. Pembentukan Pengetahuan Sains, Teknologi dan Masyarakat dalam Pandangan Pendidikan IPA. Educare: Jurnal Pendidikan dan Budaya, 1(2): 29-36.

[52] Wisudawati, A. W., dan Sulistyowati, E. 2014. Metodologi Pembelajaran IPA. Jakarta: Bumi Aksara.

[53] Wulandari, N., dan Sholihin, H. 2016. Analisis Kemampuan Literasi Sains pada Aspek Pengetahuan dan Kompetensi Sains Siswa SMP pada Materi Kalor. Edusains, 8(1): 66-73. 